\title{
Flowering does not decrease vegetative competitiveness of Lolium perenne
}

Thiele, Jan; Jørgensen, Rikke B.; Hauser, Thure Pavlo

Published in:

Basic and Applied Ecology

DOI:

10.1016/j.baae.2008.04.002

Publication date:

2009

Document version

Early version, also known as pre-print

Citation for published version (APA):

Thiele, J., Jørgensen, R. B., \& Hauser, T. P. (2009). Flowering does not decrease vegetative competitiveness of Lolium perenne. Basic and Applied Ecology, 10(4), 340-348. https://doi.org/10.1016/j.baae.2008.04.002 
This is the peer-reviewed version of the following article:

\section{Flowering does not decrease vegetative competitiveness of Lolium perenne}

This article was published in Basic and Applied Ecology, 10, Thiele $\mathrm{J}^{1}$, Jørgensen $\mathrm{RB}^{2}$, Hauser $\mathrm{TP}^{1^{*}}$, Flowering does not decrease vegetative competitiveness of Lolium perenne, 340-348, Copyright Elsevier, (2009), DOI 10.1016/j.baae.2008.04.002.

The original publication is available at www.sciencedirect.com.

\section{Summary}

The theory of life-history evolution commonly assumes a trade-off between sexual and vegetative reproduction. Hence, production of flowers and fruits should have measurable costs in terms of reduced vegetative growth. This trade-off may be meaningful for breeding of forage and turf grasses as reduced flowering could free resources and increase productivity. But if so, less-flowering cultivars might be more competitive and invade natural swards. We tested for costs of sexual reproduction on vegetative propagation and competitiveness of the perennial grass Lolium perenne, one of the most important forage and turf grasses worldwide. We used the differences in vernalization requirement between northern and southern European provenances to manipulate the degree of flowering. Over three growing seasons, we counted the number of flower stems and measured the clone diameter. The vernalization treatments were successful in producing clones with largely differing degrees of flowering. However, we found no negative correlation between flowering and vegetative propagation and competitiveness. Early and strongly flowering southern provenances showed less clonal growth and higher mortality, but within provenances the response of clone diameter to flowering was positive or neutral. We conclude that investment of resources into flowering has no measurable costs on vegetative propagation and competitiveness of $L$. perenne. The apparent lack of costs of sexual reproduction could be explained by bet-hedging strategy that is focused on survival and growth rather than reproductive effort in order to maximize the life-time fitness.

\section{KEYWORDS}

allocation trade-off, bet-hedging, clonal propagation, costs of sexual reproduction, forage productivity, invasion, plant breeding, turf grass, vernalization

\footnotetext{
${ }^{1}$ University of Copenhagen, Department of Ecology, Rolighedsvej 21, 1958 Frederiksberg C, Denmark

2 Technical University of Denmark (DTU), Ris $\varnothing$ National Laboratory, Frederiksborgvej 399, P.O. Box 49, 4000 Roskilde, Denmark
}

* Corresponding author. Tel.: +45 3533 2818; fax: +45 35332821.

E-mail address: tpha@life.ku.dk (T.P. Hauser). 


\section{Zusammenfassung}

In der Theorie der Evolutionsbiologie wird gemeinhin ein Trade-off zwischen sexueller und vegetativer Reproduktion vermutet. Demzufolge sollte die Produktion von Blüten und Früchten messbare Kosten in Form von reduziertem vegetativen Wachstum haben. Dieser Trade-off könnte von Bedeutung für die Züchtung von Futter- und Rasengräsern sein, da verringertes Blühen Ressourcen freisetzen und die Produktivität erhöhen könnte. Aber wenn dem so ist, könnten die weniger blühenden Zuchtformen erhöhte Konkurrenzkraft besitzen und natürliche Grasbestände invadieren. Wir haben die Kosten sexueller Reproduktion für die vegetative Ausbreitung und die Konkurrenzstärke des ausdauernden Wirtschaftsgrases Lolium perenne untersucht. Dabei haben wir die unterschiedlichen Vernalisierungsansprüche nord- und südeuropäischer Provenienzen genutzt, um die Blühintensität zu manipulieren. Über drei Vegetationsperioden hinweg haben wir die Anzahl der Blütenstengel gezählt und den Durchmesser der Pflanzen (Klone) gemessen. Die unterschiedlichen Vernalisierungsvarianten waren erfolgreich darin, Pflanzen mit stark variierender Blühintensität hervorzubringen. Jedoch konnten wir keine negative Korrelation zwischen Blühen und vegetativer Ausbreitung bzw. Konkurrenzstärke finden. Die früh und reichlich blühenden südlichen Provenienzen wiesen geringeres klonales Wachstum und höhere Mortalität auf, aber innerhalb der Provenienzen war die Beziehung zwischen Klondurchmesser und Blühen stets positiv oder neutral. Wir schließen daraus, dass die Investition von Ressourcen in Blütenproduktion keine messbaren Kosten für die vegetative Ausbreitung und Konkurrenzstärke von $L$. perenne hat. Das Nichtvorhandensein von Kosten sexueller Reproduktion könnte durch bet-hedging-Strategie erklärt werden, die darauf abstellt, Investitionen in sexuelle Reproduktion $\mathrm{zu}$ beschränken um Überleben und Wachstum zu gewährleisten und dadurch die lebenszeitliche Gesamtfitness zu maximieren.

\section{Introduction}

Forage and turf grasses are of high economic importance for the multi-billion dollar livestock and turfgrass industries (Bouton, 2007). Hence, plant breeders make considerable efforts to improve stress tolerance (e.g. Waldron, Ehlke, Wyse, \&Vellekson, 1998; Zhang, Mian, \& Bouton, 2006), resistance to pathogens (e.g. Bonos, Clarke, \& Meyer, 2006; Han, Bonos, Clarke, \& Meyer, 2006), and forage productivity and quality (Humphreys, 1991; Woodfield \& Easton, 2004). Breeding programs have achieved considerable advances during recent decades regarding stress tolerance and resistance, but the improvement of the productivity of forage grasses appears to have reached a plateau which may be attributable to trade-offs between productivity, stress tolerance and herbivore defense (Nelson \& Burns, 2006; Sathish, Withana, Biswas, Bryant, Templeton, et al., 2007).

Plant breeders as well as evolutionary biologists have hypothesized a trade-off between resource allocation to sexual reproduction and vegetative growth. This tradeoff may be important for breeding as sexual reproduction could reduce the vegetative productivity and persistence of forage and turf grasses (Cattani, 2003). Moreover, flower stems and inflorescences reduce the digestibility and the nutritional value of the forage (Baron, Dick, \& King, 2000). Therefore, delaying or suppressing of flowering plays an important role in current breeding programs and is a focus area of genetic modification (Jensen, Salchert, Gao, Andersen, Didion, et al., 2004).

In a general sense, trade-offs are defined as negative associations between two phenotypic traits as a consequence of genetic or physiological constraints (Mole, 
1994). Physiological trade-offs are based on the concept of proportional allocation of limited resources to competing traits under the constraint that the total amount of resource remains constant (Lloyd, 1988). Hence, an increase in allocation to one trait should result in an equivalent decrease in another (Mole, 1994; Roff \& Fairbairn, 2007). Therefore, the maintenance of a particular trait involves costs that can be quantified in terms of the reduction in fitness parameters related to other traits (Jongejans, de Kroon, \& Berendse, 2006). For example, investment of resources into flowers and seeds can involve reduced somatic growth or rhizome production (e.g. Ronsheim \& Bever, 2000; Thompson \& Eckert, 2004). Conversely, plants that avoid sexual reproduction - whether evolved naturally or produced by plant breeding might show stronger vegetative growth and vigour than their sexually reproducing conspecifics. For instance, sterile populations of Decodon verticillatus show increased winter survival (Dorken, Neville, \& Eckert, 2004). Hence, less-flowering cultivars of forage and turf grasses might be more competitive than their native conspecifics and become invasive in natural swards.

However, evidence of trade-offs between sexual reproduction and vegetative growth or propagation is ambiguous (Reznick, Nunney, \& Tessier, 2000; Obeso, 2002; Roff \& Fairbairn, 2007). Further, it is known that reproductive allocation may change in response to competition (Sgro \& Hoffmann, 2004; Weiner, 2004), but it has not clearly been tested whether allocation to sexual reproduction affects the competitiveness of clonal plants.

The aim of our experimental study was to test for effects of flowering on the competitive ability of perennial clonal grasses. We tested northern European provenances of Lolium perenne L. against central and southern European ones which differ considerably in their vernalization requirement for primary induction of flowering (Aamlid, Heide, \& Boelt, 2000). The same genet combinations were distributed over four different cold treatments to produce pairs of competing clones with varying degrees of flowering. We hypothezised that reduced flowering should result in increased competitive ability measurable in terms of higher rhizome production and, consequently, larger clone diameters.

\section{Materials and methods}

\section{Study species}

Lolium perenne L. is an important forage and turf grass in almost all temperate regions of the world (Sathish et al., 2007). It is a caespitose perennial hemicryptophyte which produces both vegetatively and sexually (Beddows, 1967). The vernalization requirement for primary floral induction shows a high variability among individual L. perenne plants (Kleinendorst, 1973). But in general, northern provenances require several weeks of exposure to cold temperatures and short days, whereas mediterranean provenances have little or no need for vernalization (Beddows, 1967; Aamlid et al., 2000). In this study, we used 6 provenances of L. perenne (3 cultivars and 3 wild sibs) from northern, central, and southern Europe (Table 1). For the central European cultivar, Aamlid et al. (2000) found a vernalization requirement for full flowering of more than 9 weeks at $6{ }^{\circ} \mathrm{C}$, whereas the southern European cultivar needed only 0-3 weeks.

\section{Experiment}

From each of the six provenances a surplus of seeds was sown into trays, and after ca. two weeks the seedlings were transplanted individually to small pots. After 
approximately four months of growth in a greenhouse, the individual plants (genets) were divided into four clones of three tillers each and planted pairwise into $13-\mathrm{cm}$ pots with standard potting soil. One clone from a northern provenance (Sisu, Bolu) was planted together with a clone from a central (Baca,Bile) or southern (Veyo, Deru) provenance (Fig. 1). Eight provenance combinations were thus created, which were replicated 20 times using different genet pairs. A given pair of genets was replicated in four pots, one for each of the vernalization treatments (see below), amounting to 640 pots in total ( 8 provenance combinations $* 20$ genet pairs $* 4$ vernalization treatments).

Table 1. Provenances of Lolium perenne used in this study.

\begin{tabular}{|c|c|c|c|c|}
\hline Name & Origin & Type & Source & $\begin{array}{l}\text { vernalization } \\
\text { requirement } \\
\left(6^{\circ} \mathrm{C}\right)^{1}\end{array}$ \\
\hline Sisu & northern & cultivar & DFL-Trifolium A/S, Store Heddinge, DK & \\
\hline Bolu & northern & wild & Own collection, Denmark, $55^{\circ} 42^{\prime} 11^{\prime \prime} \mathrm{N} ; 12^{\circ} 05^{\prime} 56^{\prime \prime} \mathrm{E}$ & \\
\hline Baca & central & cultivar & $\begin{array}{l}\text { Research Institute of Crop Production Praha-Ruzyne, Cz; } \\
\text { acc. no.: RICP 14G2000010 }\end{array}$ & $>9$ weeks \\
\hline Bile & central & wild & $\begin{array}{l}\text { Oseva Pro Ltd. Grassland Research Station Zubri; acc.no.: } \\
\text { 14G2000506 }\end{array}$ & \\
\hline Veyo & southern & cultivar & $\begin{array}{l}\text { Genetic Resources Unit, Institute of Grassland and } \\
\text { Environmental Research, Aberystwyth, UK; acc. no.: } \\
\text { ABY-BA 10064.00U }\end{array}$ & $0-3$ weeks \\
\hline Deru & southern & wild & Ibid.; acc. no.: ABY-BA 8480.00U & \\
\hline
\end{tabular}

${ }^{1}$ From Aamlid et al. (2000).

After another three months of growth, the pots were split into four groups, each containing a full replicate of the provenance and clone combinations. These groups were subjected to different length of cold treatment in climate chambers at Ris $\varnothing$ National Laboratory to induce flowering: $0,3,6$, and 12 weeks at $5-6{ }^{\circ} \mathrm{C}$ with 8 hours light daily. When not in the cold rooms, plants were kept at $12{ }^{\circ} \mathrm{C}$ during day and night.

When all vernalization treatments were finished, the plants were kept at 18 hours day length (light intensity: $400 \mathrm{mmol} / \mathrm{m}^{2 *} \mathrm{sec}$ ) with $18{ }^{\circ} \mathrm{C}$ during the day and $15^{\circ} \mathrm{C}$ at night. Approximately one month after the end of the vernalization treatments, we counted the number of flower stems on each clone. The plants were then cut to 5 $\mathrm{cm}$ height and two perpendicular diameters were measured holding the outer stems vertically. The average of these two measurements was taken as the clone diameter. We repeated vernalization treatments and measurements three times: April-July 2002, October 2002 - January 2003, and June-August 2003. The pots received the same vernalization treatment each time and were regularly rotated during vernalization and growth periods.

\section{Data analysis}

As the average clone diameters differed among vernalization treatments due to longer or shorter time of exposure to cold temperatures, we used adjusted values, i.e. we substracted the mean within each vernalization treatment, in all graphical and statistical analyses. We looked for effects of the degree of flowering and, alternatively, the presence or absence of flowers on clone diameter and relative growth of the clone. 


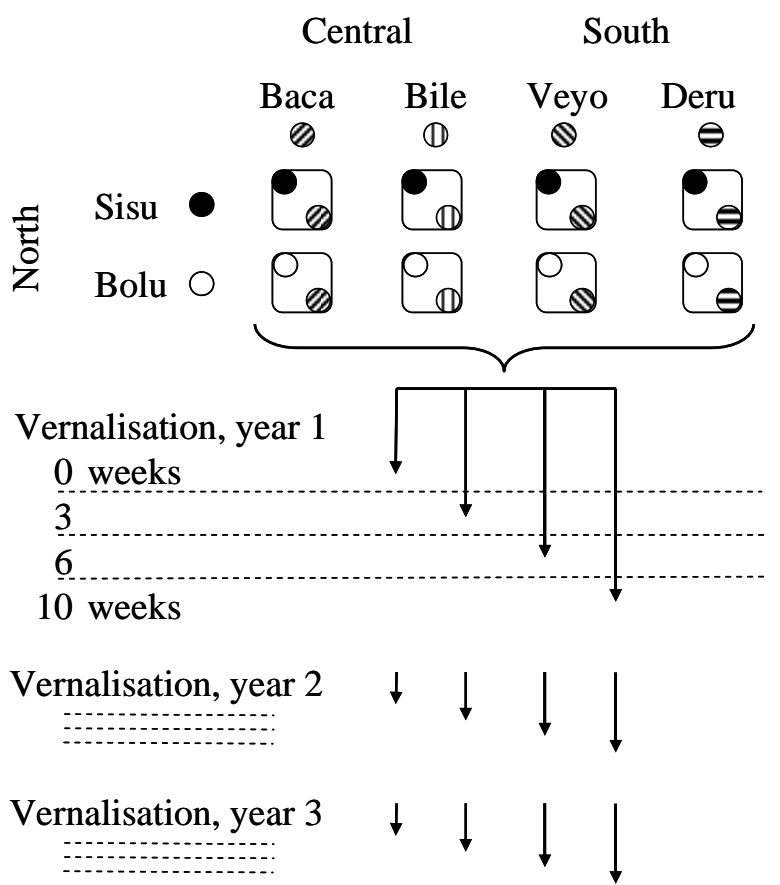

Figure 1. Scheme of the experimental design. Clones of northern provenances of Lolium perenne (Sisu, Bolu) were planted into pots together with Central (Baca, Bile) or Southern (Veyo, Deru) European clones. We subjected 20 replicates of the provenance combinations to each of four different vernalization treatments. Vernalizations and subsequent measurements were repeated over three growing seasons.

For graphical analyses, we used the lattice package (Deepayan Sarkar, 2006) in R-2.4.1 (R Development Core Team, 2006). We explored the relationship between the sum of flower stems produced by a clone and the clone's diameter with simple regressions for each single genet and each measurement time point using the lmList function of the NLME package v. 3.1-81 (Pinheiro, Bates, DebRoy, \& Sarkar, 2007) in R. Then, we tested the effect of the number of flower stems on the clone's diameter using the whole data set, i.e. all clones and measurement time points, in a repeated measures analysis with a linear mixed effects model in SAS 9.1 (@) 2002-2003 by SAS Institute Inc., Cary, NC, USA.). The basic form of this regression model was

diameter $\sim \mathrm{b}_{0}+\mathrm{b}_{1} \star$ time.

Hypothesizing that the diameter at the first measurement date $\left(b_{0}\right)$ as well as the growth of the clones thereafter $\left(b_{1}\right)$ depends on the number of flower stems produced (flowers), the diameter of the competing clone (codiam), and the provenance (prov), we replaced the intercept $\left(b_{0}\right)$ and the regression coefficient $\left(b_{1}\right)$ with the following formula:

$\mathrm{b}_{0}$ and $\mathrm{b}_{1} \sim$ flowers + codiam + prov.

Thus, we constructed a "coefficients-as-outcomes" model (Fox, 2002) with the formula

diameter $\sim$ flowers*time + codiam*time + prov*time.

The repetition of the same genet combinations over vernalization treatments allowed us to account for genotypic variation by including a random intercept at the genet level. Possible auto-correlation of plant individuals along the time series was modelled by a respective correlation structure (corAR1 in the NLME package). As the residual variance increased over time, we allowed for separate variance estimates for each time point. 
As we used provenances with different vernalization requirements to create pairs of competing clones with different degree of flowering, one might expect some degree of collinearity in the regression model that included both flowering and provenance. Pooled over all vernalistion treatments there were, however, no substantial differences in the number of flower stems produced by the different provenances. We tested for collinearity in the set of predictor variables by calculating regression models of the numerical predictors (flowers, codiam) on the remaining predictor variables. These regressions confirmed that there was no collinearity.

\section{Results}

$70 \%$ of the clones flowered at least once during the experiment. The percentage of flowering clones and the sum of flower stems per clone differed between vernalization treatments and provenances. In the short vernalization treatments $(0$ or 3 weeks), $48 \%$ of the northern provenances (Sisu, Bolu) and $79 \%$ of the southern ones (Veyo, Deru) flowered. In the full vernalization (12 weeks) the figures were $99 \%$ and $95 \%$, respectively. During the first flowering phase and also in total, the southern provenances produced considerably more flower stems than the central European Baca and the northern ones, while the central European Bile was intermediate. Thus, the vernalization treatments were successful in producing combinations of clones with varying degrees of flowering.

There were no obvious differences in diameter and growth between flowering and non-flowering clones of the central and northern provenances. In the southern provenances, flowering clones were larger than non-flowering clones (Fig. 2, 3). We found considerable variability among genets of the correlation between the number of flower stems and the clone diameter. However, none of the medians of the correlation coefficients, calculated within each provenance, did deviate significantly from zero (Fig. 4). All in all, the number of flower stems of a clone was slightly positively correlated with the clone's diameter (Table 2). This correlation became more positive towards the third measurement (see the significant negative interactions of flowers with time 1 and 2).

The early and strongly flowering southern provenances (Veyo, Deru) had significantly lower diameters than the central European and northern ones (Sisu, Bolu, Baca) except for the central European Bile, which was again intermediate (Table 2). The differences between the southern provenances and the others increased over time. The southern provenances also showed considerably higher mortality rates (Veyo 25\%, Deru 46\%) than the central and northern European (Baca 2\%, Bile 6\%, Sisu 5\%, Bolu 2\%). In general, the diameters of the two competing clones of the same pot were negatively correlated.

\section{Discussion}

We manipulated the flowering of Lolium perenne plants through different length of vernalization assuming other life-history traits that control resource uptake and allocation to be independent of these treatments. A general reservation about testing phenotypic correlations is, however, that the two traits in question, here flowering and vegetative growth, could be under the control of common factors that might themselves be affected by the experimental treatments. If, for instance, vernalization treatments would stimulate or inhibit resource uptake or allocation ratios, then true trade-offs could be masked or false trade-offs could be pretended. Yet there is no indication that vernalization treatments might have affected allocation patterns apart from the deliberate manipulation of flowering and the slightly retarded growth in the 

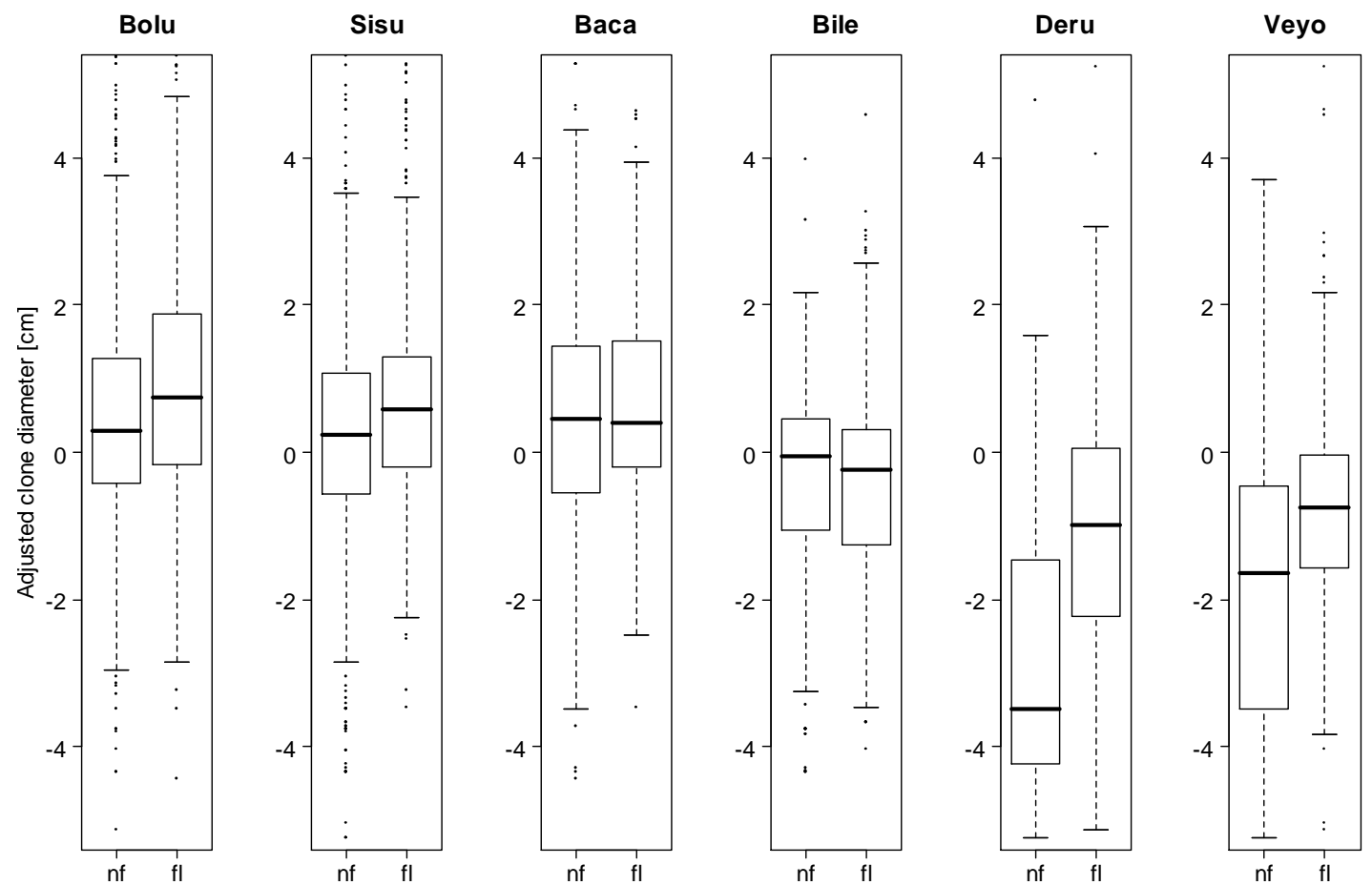

Figure 2. Boxplots of diameters of flowering (fl) and non-flowering (nf) clones for six different provenances of Lolium perenne. The data comprise three time points of measurement approx. 7 months apart. The status of flowering of a clone could change from one time point to another. Diameters were adjusted in order to balance mean differences between different vernalization treatments. Bold lines represent medians, boxes indicate quartiles, whiskers show 1.5 times the interquartile range.
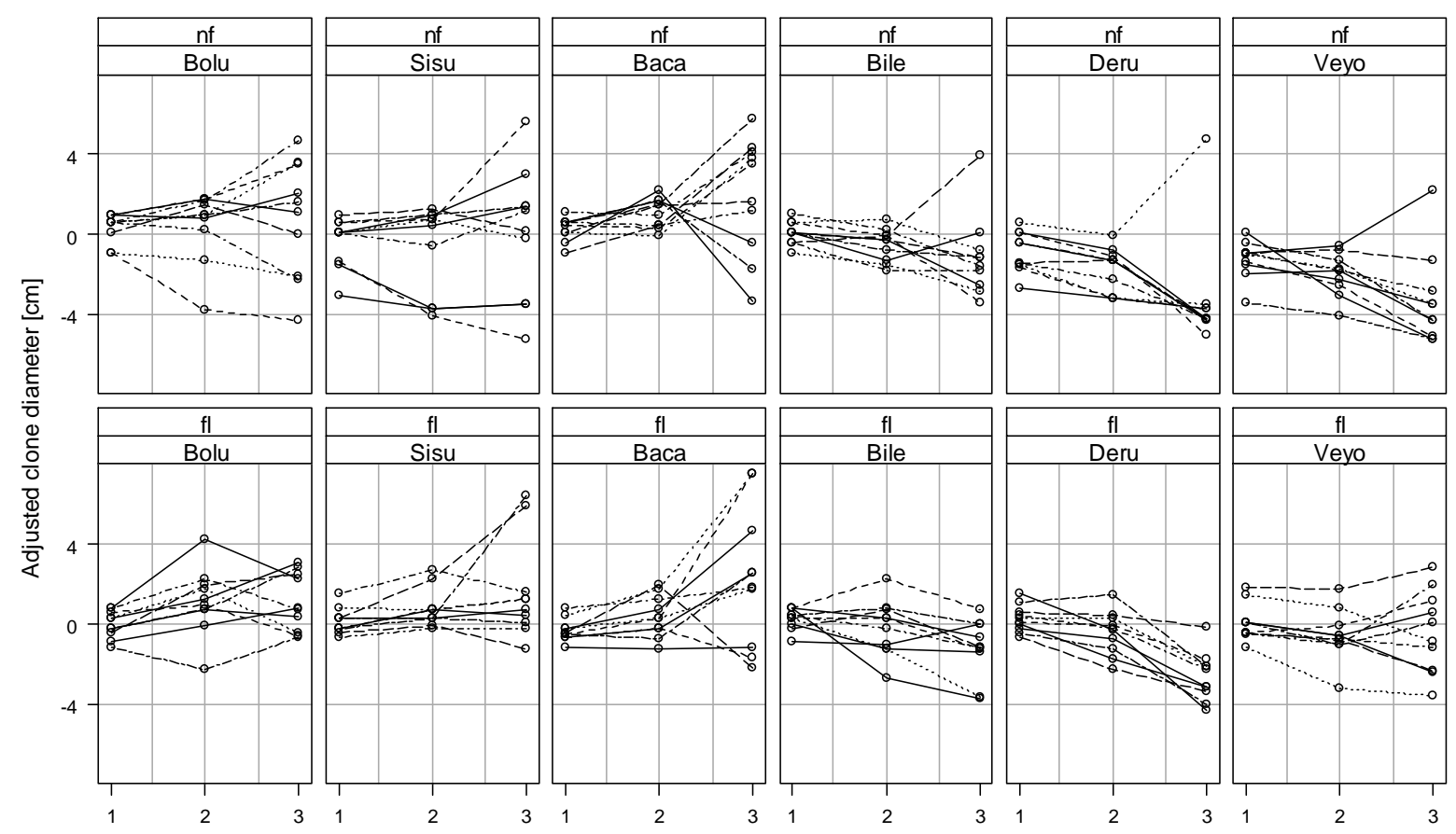

Figure 3. Development of clone diameters over three time points (measurements each 7 months apart) for flowering (fl) and non-flowering (nf) plants of six provenances of Lolium perenne. Each panel displays a random sample comprising 10 clones. Clones that produced only between 1 and 20 flower stems over the whole duration of the experiment were excluded. Diameters were adjusted in order to balance mean differences between vernalization treatments. 

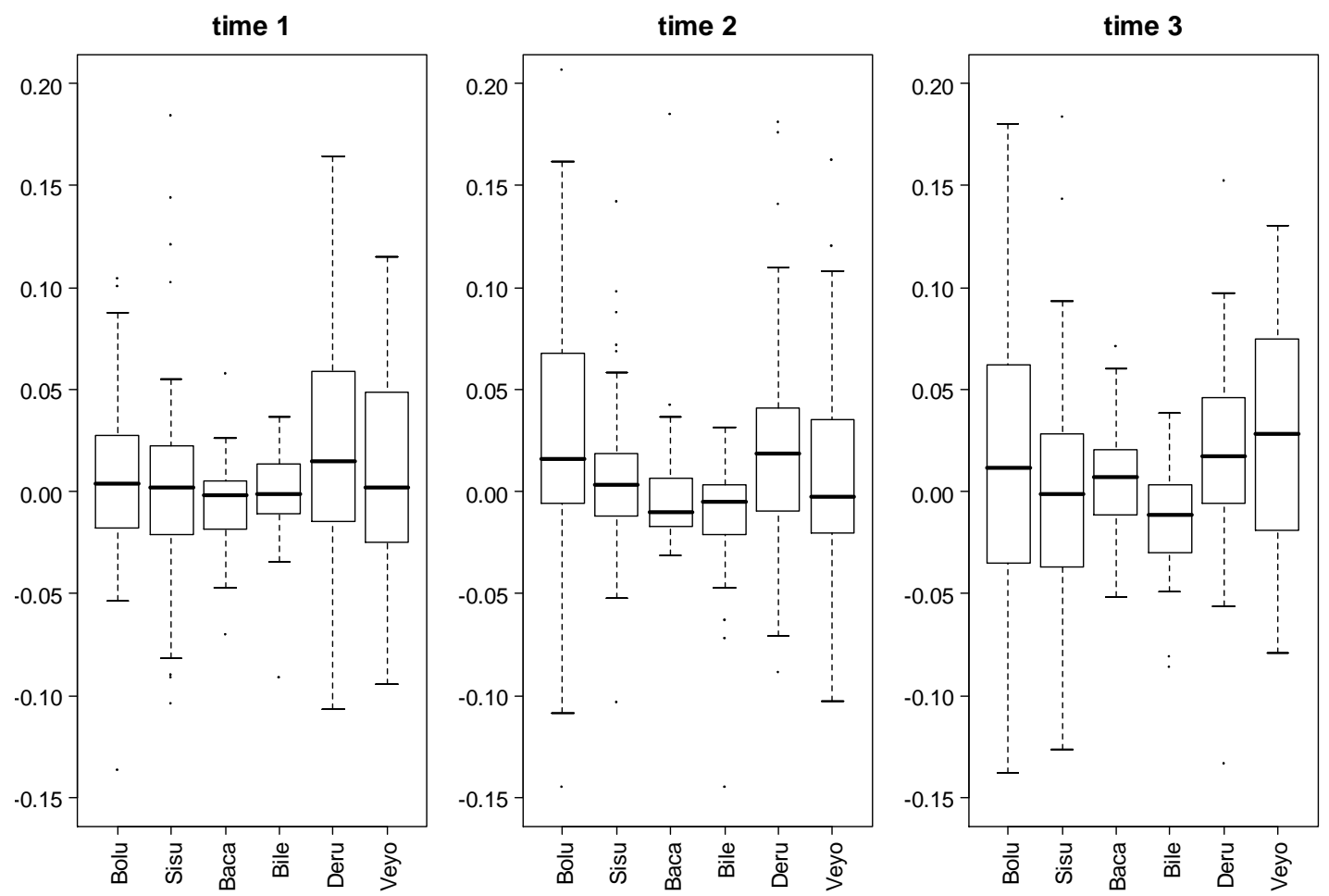

Figure 4. Boxplots of regression coefficients for each single genet of the regression model: clone diameter sum of flower stems. Separate sets of this model were calculated for six different provenances of Lolium perenne and three chronological measurements approx. 7 months apart. Bold lines represent medians, boxes indicate quartiles, whiskers show 1.5 times the interquartile range. The sample size, i.e. number of regression coefficients, per boxplot was 80 for the northern provenances (Sisu, Bolu) and 40 for the other provenances.

longer vernalization treatments which was controlled for in the statistical analyses. Thus, we start out the following discussion from the assumption that flowering was manipulated independently of other factors.

Our study of Lolium perenne showed no negative correlation of both the presence and the number of flowering stems with vegetative propagation measured as clone diameter. In fact, the number of flower stems was slightly positively related to clone diameter (Table 2), but there was a high variability of diameters among both flowering and non-flowering clones (Fig. 2). The clone diameter was affected by competition and by variation among provenances and genets. The southern European provenances produced the most flower stems and, at the same time, had lower clone diameters and higher mortality rates than the central and northern European provenances. Although this observation would suggest a negative effect of flowering on vegetative growth at the provenance level, the southern European provenances showed a marked positive relationship between clone diameter and flowering (Fig. 2). Their smaller clone diameters may be explained by lesser persistence of their tillers which is characteristic for early flowering sibs (Beddows, 1967). Hence, our study indicates life-cycle differences among provenances and genets but gives no evidence for a trade-off between sexual reproduction and vegetative propagation in clonal grasses.

Similar to our findings, no negative correlation was found between allocation to infructescenses and rhizomes in the clonal grass Agropyron repens, but considerable variation in allocation patterns among provenances and environments 
(Reekie, 1991). In Festuca rubra ssp. rubra, the incidences of both flowering and production of new tillers increased with increasing shoot size (Hara \& Herben, 1997). On the whole, several correlational studies did find trade-offs between sexual and clonal reproduction in plants (e.g. Prati \& Schmid, 2000; Ronsheim \& Bever, 2000; van Kleunen, Fischer, \& Schmid, 2002; Thompson \& Eckert, 2004), but there are others that found no negative correlations or even positive ones (e.g. Saikkonen, Koivunen, Vuorisalo, \& Mutikainen, 1998; Verboom, Stock, \& Linder, 2002; Weppler \& Stöcklin, 2005; see Obeso, 2002 for a recent review).

Table 2. Repeated-measures linear mixed-effects (LME) model of clone diameters of Lolium perenne. Measurements of clone diameter at three time points were regressed on the number of flower stems of the clone (flowers), the diameter of the competing clone of the same pot (codiam), the identity of the $L$. perenne provenance (prov) and the time point of measurement (time, factor levels 1, 2, 3). The same genets were repeated in four different vernalization treatments to induce different degrees of flowering. The model included a random intercept at the genet level and an auto-regressive term to account for correlation over time. The significance of main effects was tested by Type-III-Likelihood-Ratio tests (F-values); significance of single factor levels was tested by t-tests (t-values).

\begin{tabular}{lllllll}
\hline effect & & & & & F/t & \\
blom & factor level & coef. & error & DF & value & p-level \\
codiam & & 0.029 & 0.004 & 1 & 69.33 & $<.0001$ \\
prov & & -0.134 & 0.023 & 1 & 69.07 & $<.0001$ \\
& & & & 5 & 72.72 & $<.0001$ \\
& Sisu & 2.597 & 0.265 & 3443 & 9.80 & $<.0001$ \\
& Bolu & 2.820 & 0.263 & 3443 & 10.73 & $<.0001$ \\
& Baca & 3.098 & 0.293 & 3443 & 10.59 & $<.0001$ \\
& Bile & 0.462 & 0.290 & 3443 & 1.59 & 0.1114 \\
time & Deru & -1.344 & 0.289 & 3443 & -4.66 & $<.0001$ \\
& & & & 2 & 21.13 & $<.0001$ \\
& 1 & 1.198 & 0.193 & 3443 & 6.21 & $<.0001$ \\
blom*time & 2 & 0.848 & 0.179 & 3443 & 4.74 & $<.0001$ \\
& & & & 2 & 15.01 & $<.0001$ \\
& 1 & -0.024 & 0.004 & 3443 & -5.42 & $<.0001$ \\
& 2 & -0.020 & 0.004 & 3443 & -4.65 & $<.0001$ \\
codiam*time & & & & 2 & 12.22 & $<.0001$ \\
& 1 & 0.069 & 0.031 & 3443 & 2.21 & 0.0274 \\
& 2 & -0.049 & 0.026 & 3443 & -1.88 & 0.0602 \\
& & & & 10 & 55.77 & $<.0001$ \\
\hline
\end{tabular}

explained variation $\left(\mathrm{McFadden}{ }^{\prime} .\right\lrcorner_{0^{\mathrm{t}}}$

Whole model 0.278

Fixed effects 0.121

Random genet effect 0.079

There are serveral possible explanation for the absence of negative correlations between allocation to sexual and vegetative plant functions. In general, trade-offs between plant components may be masked by high variation in resource uptake and plant size compared to variation in resource allocation. Then large plants may be able to invest more into both vegetative and generative functions compared to small plants, which can lead to postitive correlations (van Noordwijk \& de Jong, 1986; Reznick et al., 2000; Jongejans, 2004; Roff \& Fairbairn, 2007). We partly overcame this limitation of correlational studies of trade-offs by manipulating the flowering of the same genet pairs, which should have a constant capacity for resource 
uptake, through different vernalization treatments. However, even on the genet level we found no overall negative correlation between flowering and vegetative propagation.

According to theory, no trade-off between sexual and vegetative allocation would be expected when growth is not limited by resources or meristems (Geber, 1990; Obeso, 2002; Jongejans, 2004). Meristem limitation appears to be unlikely in clonal grasses as they have quiescent meristems. However, the significant competition between the clones indicated that resources were limiting. Further, several recent studies found that trade-offs, if extant, are not weaker under high resource supply (e.g. Saikkonen et al., 1998; Ronsheim \& Bever, 2000). Thus, it appears unlikely that a high resource level concealed a trade-off in this study.

Notwithstanding trade-offs, it may be that costs of sexual reproduction are compensated by photosynthesis of the inflorescenses themselves (McDowell, McDowell, Marshall, \& Hultine, 2000; Jongejans, 2004). The inflorescenses of woody plants cover between $2.3 \%$ and $64.5 \%$ of their carbon demand by their own photosynthesis (Watson \& Casper, 1984; McDowell et al., 2000). For the annual herb Ambrosia trifida this percentage was $41 \%$ and $57 \%$ for male and female inflorescenses, respectively (Bazzaz \& Carlson, 1979). Further compensating mechanisms are stimulaton of increased photosynthesis or increased resource uptake of other plant parts (Watson \& Casper, 1984; Lehtilä \& Syrjänen, 1995), or nutrient resorption from senescent reproductive structures (Obeso, 2002). Hence, the net costs of sexual reproduction for non-reproductive tissue can be considerably lower than the actual energy consumption of the inflorescenses.

The positive correlation between sexual reproduction and vegetative propagation in $L$. perenne could be explained by plant size variation in combination with allometric resource allocation (Weiner, 2004). Usually plants must exceed a threshold size before they can start to reproduce (Weiner, 1988). Further, plants with a larger body can potentially produce more flowers because they have more resources available which they can invest into a higher number of meristems.

We think, the most parsimonious explanation for the apparent lack of costs of sexual reproduction in $L$. perenne clones may be that the net investment into sexual structures is low compared to vegetative structures. Hence, the physiological tradeoff, which is likely to exist, is weak and undetectable. The notion that $L$. perenne plants curb their reproductive effort so that it does not reduce survival and growth would be in accord with the bet-hedging hypothesis (Stearns, 1976). Under high juvenile mortality compared to adult mortality, it predicts that perennial plants should evolve allocation strategies that favour survival and involve only moderate reproductive effort in order to optimise their life-time fitness.

\section{Conclusions}

Costs of sexual reproduction for vegetative propagation appear to be negligible in Lolium perenne. There are no signs of increased competitive ability of clones due to reduced flowering. Hence, less-flowering plants could probably not invade natural swards. It appears that reduction of flowering would not enhance the turf performance of $L$. perenne in terms of vegetative propagation. An increase of productivity of vegetative plant parts appears to be unlikely, although we did not measure productivity directly. However, we cannot fully exclude that there might be some genets with significant positive responses to release from flowering. 


\section{Acknowledgements}

The EU project CONFLOW (QLRT-2000-01412) and the project "Living with biotechnology" funded by the Danish Agency for Science and Innovation (20002003) are acknowledged for grants supporting this research. We thank Jacob Weiner for checking the manuscript and helpful comments. Claus Ekstrøm gave statistical advice on the regression analyses. Last but not least, we thank a number of colleagues at Risø National Laboratory for help with the experiment.

\section{References}

Aamlid, T.S., Heide, O.M., \& Boelt, B. (2000). Primary and secondary induction requirements for flowering of contrasting European varieties of Lolium perenne. Annals of Botany, 86, 10871095.

Baron, V.S., Dick, A.C., \& King, J.R. (2000). Leaf and stem mass characteristics of cool- season grasses grown in the Canadian grassland. Agronomy Journal, 92, 54-63.

Bazzaz, F.A., \& Carlson, R.W. (1979). Photosynthetic contribution of flowers and seeds to reproductive effort of an annual colonizer. New Phytologist, 82, 223-232.

Beddows, A.R. (1967). Lolium perenne L. Journal of Ecology, 55, 567-587.

Bonos, S.A., Clarke, B.B., \& Meyer, W.A. (2006). Breeding for disease resistance in the major coolseason turfgrasses. Annual Review of Phytopathology, 44, 213-234.

Bouton, J. (2007). The economic benefits of forage improvement in the United States. Euphytica, 154, 263-270.

Cattani, D.J. (2003). Divergent selection for flowering in annual blue grass and its impact on plant development and turfgrass utility. Canadian Journal of Plant Science, 83, 157-161.

Deepayan Sarkar (2006). lattice: Lattice Graphics. R package version 0.14-16.

Dorken, M.E., Neville, K.J., \& Eckert, C.G. (2004). Evolutionary vestigilization of sex in a clonal plant: selection versus neutral mutation in geographically peripheral populations. Proceedings of the Royal Society London B, Biological Sciences, 271, 2375-2380.

Fox, J. (2002). Linear mixed models. Appendix to an R and S-PLUS companion to applied regression. http://cran.r-project.org/doc/contrib/Fox-Companion/appendix-mixed-models.pdf, last viewed 29. June 2007.

Geber, M.A. (1990). The cost of meristem limitation in Polygonum arenastrum: negative genetic correlations between fecundity and growth. Evolution, 44, 799-819.

Han, Y., Bonos, S.A., Clarke, B.B., \& Meyer, W.A. (2006). Inheritance of resistance to grey leaf spot disease in perennial ryegrass. Crop Science, 46, 1143-1148.

Hara, T., \& Herben, T. (1997). Shoot growth dynamics and size-dependent shoot fate of a clonal plant, Festuca rubra, in a mountain grassland. Researches on Population Ecology, 39, 83-93.

Humphreys, M.O. (1991). A genetic approach to the multivariate differentiation of perennial ryegrass (Lolium perenne L.) populations. Heredity, 66, 437-443.

Jensen, C.S., Salchert, K., Gao, C., Andersen, C., Didion, C., \& Nielsen, K.K. (2004). Floral inhibition in red fescue (Festuca rubra L.) through expression of a heterologous flowering repressor from Lolium. Molecular Breeding, 13, 37-48.

Jongejans, E. (2004). Life history strategies and biomass allocation: the population dynamics of perennial plants in a regional perspective. $\mathrm{PhD}$ thesis, Wageningen University, The Netherlands.

Jongejans, E., de Kroon, H., \& Berendse, F. (2006). The interplay between shifts in biomass allocation and costs of reproduction in four grassland perennials under simulated successional change. Oecologia, 147, 369-378.

Kleinendorst, A. (1973). Some effects of vernalization on the reproductive capacity of Lolium perenne L. Netherlands Journal of Agricultural Science, 22, 6-21.

Lehtilä, K., \& Syrjänen, K. (1995). Positive effects of pollination on subsequent size, reproduction, and survival of Primula veris. Ecology, 76, 1084-1098.

Lloyd, D.G. (1988). A general principle for the allocation of limited resources. Evolutionary Ecology, 2, 175-187.

McDowell, S.C.L., McDowell, N.G., Marshall, J.D., \& Hultine, K. (2000). Carbon and nitrogen allocation to male and female reproduction in Rocky Mountain Douglas-fir (Pseudotsuga menziesii var. glauca, Pinaceae). American Journal of Botany, 87, 539-546.

Mole, S. (1994). Trade-offs and constraints in plant-herbivore defense theory: a life-history perspective. Oikos, 71, 3-12. 
Nelson, C.J., \& Burns, J.C. (2006). Fifty years of grassland science leading to change. Crop Science, 46, 2204-2217.

Obeso, J.R. (2002). The cost of reproduction in plants. New Phytologist, 155, 321-348.

Pinheiro, J., Bates, D., DebRoy, S., \& Sarkar, D. (2007). nlme: Linear and Nonlinear Mixed Effects Models. R package version 3.1-81.

Prati, D., \& Schmid, B. (2000). Genetic differentiation of life-history traits within populations of the clonal plant Ranunculus reptans. Oikos, 90, 442-456.

R Development Core Team (2006). R: A language and environment for statistical computing. R Foundation for Statistical Computing, Vienna, Austria. ISBN 3-900051-07-0, URL http://www.R-project.org.

Reekie, E.G. (1991). Cost of seeds versus rhizome production in Agropyron repens. Canadian Journal of Botany, 69, 2678-2683.

Reznick, D., Nunney, L., \& Tessier, A. (2000). Big houses, big cars, superfleas and the costs of reproduction. Trends in Ecology and Evolution, 15, 421-425.

Roff, D.A., \& Fairbairn, D.J. (2007). The evolution of trade-offs: where are we? Journal of Evolutionary Biology, 20, 433-447.

Ronsheim, M.L., \& Bever, J.D. (2000). Genetic variation and evolutionary trade-offs for sexual and asexual reproductive modes in Allium vineale (Liliaceae). American Journal of Botany, 87, 1769-1777.

Saikkonen, K., Koivunen, S., Vuorisalo, T., \& Mutikainen, P. (1998). Interactive effects of pollination and heavy metals on resource allocation in Potentilla anserina L. Ecology, 79, 1620-1629.

Sathish, P., Withana, N., Biswas, M., Bryant, C., Templeton, K., Al-Wahb, M., Smith-Espinoza, C., Roche, J.R., Elborough, K.M., \& Phillips, J.R. (2007). Transcriptome analysis reveals seasonspecific rbcS gene expression profiles in diploid perennial ryegrass (Lolium perenne L.). Plant Biotechnology Journal, 5, 146-161.

Sgro, C.M., \& Hoffmann, A.A. (2004). Genetic correlations, trade-offs and environmental variation. Heredity, 93, 241-248.

Stearns, S.C. (1976). Life-history tactics: a review of the ideas. The Quarterly Review of Biology, 51, 347

Thompson, F.L., \& Eckert, C.G. (2004). Trade-offs between sexual and clonal reproduction in an aquatic plant: experimental manipulations vs. phenotypic correlations. Journal of Evolutionary Biology, 17, 581-592.

van Kleunen, M., Fischer, M., \& Schmid, B. (2002). Experimental life-history evolution: selection on the allocation to sexual reproduction and its plasticity in a clonal plant. Evolution, 56, 21682177.

van Noordwijk, A.J., \& de Jong, G. (1986). Acquisition and allocation of resources: their influence on variation in life-history tactics. American Naturalist, 128, 137-142.

Verboom, G.A., Stock, W.D., \& Linder, H.P. (2002). Determinants of postfire flowering in the geophytic grass Ehrharta capensis. Functional Ecology, 16, 705-713.

Waldron, B.L., Ehlke, N.J., Wyse, D.L., \& Vellekson, D.J. (1998). Genetic variation and predicted gain from selection for winterhardiness and turf quality in a perennial ryegrass topcross population. Crop Science, 38, 817-822.

Watson, M.A., \& Casper, B.B. (1984). Morphogenetic constraints on patterns of carbon distribution in plants. Annual Review of Ecology and Systematics, 15, 233-258.

Weiner, J. (1988). The influence of competition on plant reproduction. In: L. Lovett Doust (Ed.), Plant reproductive ecology: patterns and strategies (pp. 228-245). New York: Oxford University Press.

Weiner, J. (2004). Allocation, plasticity and allometry in plants. Perspectives in Plant Ecology, Evolution and Systematics, 6, 207-215.

Weppler, T., \& Stöcklin, J. (2005). Variation of sexual and clonal reproduction in the alpine Geum reptans in contrasting altitudes and successional stages.Basic and Applied Ecology, 6, 305316.

Woodfield, D.R., \& Easton, H.S. (2004). Advances in pasture plant breeding for animal productivity and health. New Zealand Veterinary Journal, 52, 300-310

Zhang, Y., Mian, M.A.R., \& Bouton, J.H. (2006). Recent molecular and genomic studies on stress tolerance of forage and turf grasses. Crop Science, 46, 497-511. 